Thorning, L. 1976: Aeromagnetic surveys in southern and central West Greenland between $63^{\circ}$ and $71^{\circ}$ N. Rapp. Grønlands geol. Unders. 80, 61-65.

Thorning, L. 1977: Continuation of the aeromagnetic surveys in southern and central West Greenland between $64^{\circ}$ and $72^{\circ}$ N. Rapp. Grønlands geol. Unders. 85, 34-37.

Thorning, L., Jensen, L. B., Marcussen, C., Mielby, B. S. \& Petersen, S. A. 1978: Geophysical field work on selected aeromagnetic anomalies in central West Greenland. Rapp. Grønlands geol. Unders. 90, 38-42.

Laboratoriet for Geofysik, Geologisk Institut, Aarhus University, Finlandsgade 6, DK-8200 Arhus $N$.

\title{
International field work on Archaean gneisses in the Godthåbsfjord-Isua area, southern West Greenland
}

\author{
D. Bridgwater, J. H. Allaart, H. Baadsgaard, K. D. Collerson, I. Ermanovics, \\ B. E. Gorman, W. Griffin, G. Hanson, V. R. McGregor, S. Moorbath, \\ A. P. Nutman, P. Taylor, E. Tveten and J. Watson
}

Geoscientists representing the main research institutes who discovered and have made significant contributions to our understanding of the early crustal rocks in the North Atlantic area visited West Greenland in June 1978. The group was partially financed by Nato scientific research grant 949 and by national research organisations, universities and geological surveys in Denmark, Norway, the United Kingdom, Canada and the USA. Bridgwater, Taylor and Moorbath stayed on into July at Isua where they joined a party financed by the U.S. S.N.F. organised by C. Ponnamperuma (University of Maryland.

The field work had four main objectives.

(1) To allow scientists working in adjacent ancient shield areas in Norway, Scotland and Labrador to discuss field methods of distinguishing rock units in high grade metamorphic areas with field geologists working in Greenland.

(2) To allow discussion on the outcrop between field and laboratory based scientists in an attempt to resolve differences in interpretation.

(3) To discuss the most important problems for further research and to make collections for laboratory work.

(4) To check field evidence used to show the order of geological events and to identify various lithological units. This was particularly important in the Isua area where there has been debate both about relations between the major rock units and about the primary character of many of the highly deformed rocks within the supracrustal succession. 


\section{Major problems studied}

(1) Evidence for an early (3600-3700 m.y.) granulite facies metamorphism.

In the Qilangârssuit area (mapped by A. P. Nutman and B. Chadwick, Exeter University), inclusions of Akilia association rocks and, less commonly, the enclosing Amîtsoq gneisses locally contain relic granulite facies mineral assemblages (McGregor \& Mason, 1977). No granulite facies mineral assemblages have been found in the Malene supracrustals that are interlayered with the Amitsoq gneisses in the same area. Malene supracrustal and younger quartzo-feldspathic gneisses regarded as equivalent to the Nuk gneisses of Godthåbsfjord, outcropping $45 \mathrm{~km}$ to the east, contain granulite facies assemblages formed during the $2800 \pm 100$ m.y. metamorphic event (Black et al., 1973; Wells, 1976). Early granulite facies rocks comparable to the rocks found at Qilangârssuit have been described from the pre-3600 m.y. Nulliak assemblage in the Uivak gneisses of Labrador (Bridgwater \& Collerson, 1977; Collerson \& Bridgwater, 1979). Current $\mathrm{Pb}-\mathrm{Pb}$ whole rock studies (Taylor) show no evidence for a major isotopic re-equilibration after $3600 \mathrm{~m} . \mathrm{y}$. Studies of mineral assemblages (Griffin) suggest the granulite facies rocks were formed at temperatures and pressures comparable to those seen in younger medium pressure granulite facies terrains. According to Griffin there is no evidence of exceptional thermal gradients in this remnant of early Archaean crust. Trace element studies (Bridgwater, McGregor \& Nutman) suggest that the early high grade metamorphism may have been accompanied by a loss of $\mathrm{Rb}$ and $\mathrm{U}$. The extent of the early granulite facies metamorphism is not known. Textures in Amîtsoq grey gneisses from Narssaq suggest that these may have been affected by early granulite facies metamorphism but have since been retrogressed. Microtextural studies by Collerson \& Bridgwater (1979) on the Uivak grey gneisses in Labrador suggest a similar metamorphic history.

(2) Field versus isotopic evidence for subdivision of the gneisses and the presence of old crust in the Ameralik fjord area.

The original field division of the quartzo-feldspathic gneisses into the Amitsoq and Nuk suites which relied primarily on the identification of Ameralik dykes has coincided over the Godthåbsfjord-Isua area with the $\mathrm{Rb}-\mathrm{Sr}, \mathrm{Pb}-\mathrm{Pb}$ and $\mathrm{U}-\mathrm{Pb}$ isotopic division of the gneisses into two major age groups - an older giving ages at $3700 \pm 150 \mathrm{~m}$.y., the second at $2800 \pm 200$ m.y. (Moorbath et al., 1972, 1975; Moorbath \& Pankhurst, 1976; Baadsgaard, 1973, 1976). Outside the area in which the Amitsoq gneisses have been identified with certainty in the field there is no isotopic evidence of sialic crust older than 3000 m.y.

South of the middle section of Ameralik fjord units of gneiss identified by field characters as Amîtsoq gneiss alternate with units of Nuk gneisses, Malene supracrustals and anorthositic rocks. Amîtsoq gneisses have been traced in the field as far south as $64^{\circ} \mathrm{N}$ (McGregor) and must extend farther south than this. Most of the rocks in this area appear to be retrogressed from granulite facies and this is presumed to be equivalent to the c. 2800 m.y. granulite event south of $64^{\circ}$ since it affected Nuk gneisses. Gneisses with clearly recognisable dyke fragments identified in the field as Ameralik dykes crop out on the coast between Qasigiánguit and Kangimut sangmissoq. This gneiss unit is regarded by McGregor as be- 
longing to the same major unit as the type Amîtsoq gneisses in the outer part of Ameralik, samples of which lie on the c. 3700 m.y. Amitsoq Rb-Sr and Pb-Pb isochrons (Moorbath et al., 1972). The field work in 1978 confirmed the earlier observations that the gneisses from Kangimut sangmissoq show all the characters used to identify Amîtsoq gneisses and to distinguish them from Nuk gneisses on the outcrop, the only peculiarity being that the gneisses at this locality have been affected by a granulite facies event followed by later retrogression. $\mathbf{R b}-\mathrm{Sr}$ and $\mathrm{Pb}-\mathrm{Pb}$ isotope studies of samples from the Qasigiánguit - Kangimut sangmissoq gneiss unit give no evidence of a crustal history earlier than $3000 \mathrm{~m} . \mathrm{y}$. (Taylor \& Moorbath). Zircons from the gneisses at Kangimut sangmissoq show no isotopic evidence of a pre-3000 m.y. history for these rocks (Baadsgaard) although they are identical morphologically with zircons from Amitsoq gneisses and contain much lower Pb contents than the type 2800 m.y. Nuk gneisses from Godthåbsfjord. The U-Pb isotopic determinations support the conclusion from the $\mathrm{Rb}-\mathrm{Sr}$ and $\mathrm{Pb}-\mathrm{Pb}$ data that these rocks do not belong to the Amîtsoq gneiss suite. However, the $\mathrm{U}-\mathrm{Pb}$ work by itself is not definitive. U-Pb measurements on Malene supracrustals collected close to the Qôrqut granite give the age of the granite rather than either an age of volcanism or age of the material from which the zircons were derived (Baadsgaard, 1976). Unpublished results on inclusions of Akilia material have also shown resetting of the $\mathrm{U}-\mathrm{Pb}$ system during lead loss associated with the intrusion of the Qôrqut granite. Recent published work on zircons from supracrustal material included in $3600 \mathrm{~m} . y$. gneisses from Labrador gives U-Pb ages of $2550 \mathrm{~m} . \mathrm{y}$, the age of the intrusive granites in the area (Baadsgaard et al., in press). We are divided about whether it is possible to interpret the isotopic evidence in any way which does not invalidate the field identification of these rocks as Amîtsoq gneisses. Sm-Nd studies are now in progress (R. K. O'Nions, Lamont-Doherty Observatory).

(3) Measurements of the age of intrusion of different phases of Amîtsoq and Nuk gneisses.

The major isotopic work so far carried out on the quartzo-feldspathic gneisses has consisted of $\mathrm{Rb}-\mathrm{Sr}$ and $\mathrm{Pb}-\mathrm{Pb}$ rock studies (Oxford Isotopic Laboratory) since these methods give information about the origin of the rocks as well as an age.

As the rocks used to obtain the isochrons belong to several intrusive phases (in many cases separated by deformation) the ages obtained must be regarded as recording an overall thermal event rather than representing the precise age of intrusion of individual bodies. Current $\mathrm{U}-\mathrm{Pb}$ determinations (Baadsgaard) on zircons separated from individual intrusive phases in the Nuk and Amîtsoq gneiss suites, where these are least affected by younger events, should give more detailed resolution of the timing and duration of events within each major period of igneous activity. Preliminary results from Nuk gneisses in the Godthåb area suggest there could be a time span in the order of 100-150 m.y. between the earliest and latest phases of intrusion of Nuk gneisses, as identified in the field.

\section{Field relations between Amitsoq gneisses and Malene supracrustals}

Contacts between the Amîtsoq gneisses and Malene supracrustal rocks in the Godthåbsfjord area mapped by McGregor (1973) are regarded as tectonic and thus give no direct information either about the relative age of the supracrustals and gneisses or information 
about the depositional environment of the supracrustals. In the Qilangârssuit area some Amîtsoq-Malene boundaries are marked by a fairly continuous horizon, up to $1.5 \mathrm{~m}$ thick, of quartzite with green chrome-bearing micas. Nutman and Chadwick contend that this represents a basal sediment to the Malene supracrustal rocks deposited on an older Amitsoq gneiss basement. Most of the party considered this to be a feasible explanation of the field observations if not an absolute proof of the primary relations.

\section{Field work in the Isua area}

The following main observations were made confirming or extending earlier studies.

(1) The Amitsoq gneisses are younger than the supracrustal rocks. Gneiss sheets intrude the supracrustals along the margins of the belt. Discordant veins of gneiss, up to several tens of meters thick, occur away from the contacts in many parts of the succession. Inclusions of supracrustals are found in the gneisses on either side of the belt.

(2) No evidence was seen in the sedimentary units of material derived from earlier continental crust. Many of the units described earlier as clastic rocks are now regarded as tectonic. Where clast-rich material is recognised it is intraformational and mainly of local volcanogenic origin. The main detrital units in the succession are either acid volcanic sediments or pelitic rocks which could be derived from a variety of sources.

(3) The structures within the supracrustal belt are complex. The supracrustal rocks were already highly deformed at the time they were intruded by the Amitsoq gneisses. Both gneisses and supracrustals were strongly deformed before the injection of Ameralik dykes. We consider that many of the major lithological contacts within the succession are tectonic and regard the sequence as more likely to represent a series of thrust sheets or nappes instead of a single volcanic-sedimentary sequence with the primary order of deposition preserved.

(4) Deformation is extreme. The possibility of identifying primary sedimentary structures except for gross lithological layering is small.

(5) The supracrustal belt contains a higher proportion of sediments than is normally seen in Archaean volcanic/sedimentary successions from well preserved greenstone belts. In this respect the Isua supracrustals resemble supracrustal remnant in some high grade terrains, for example the Lewisian, the Upernavik sequence of Labrador and the supracrustal units preserved in the Nagssugtoqidian mobile belt. There are comparatively few rocks of normal basaltic composition within the succession. The amphibolite units shown on published maps (Bridgwater et al., 1976; Allaart, 1976) are composite and contain a high proportion of sediments including ironstones, impure calcareous rocks and pelites. The garben schiefer is also a highly variable basic unit with highly magnesium-rich layers with a bulk chemistry which does not correspond to either an igneous liquid or a normal cumulate of olivine, pyroxene and plagioclase. The discordant contacts between the garben schiefer and the surrounding supracrustals could at least in part be tectonic rather than intrusive and the garben schiefer need not all be derived directly from igneous parents. Whether the magnesium-rich layers could represent chemical sediments or whether they could represent basic or ultramafic igneous rocks leached and strongly modified during metamorphism is not known. Ultramafic masses (dunites and metamorphic equivalents) in the supracrustals are cut by sheets of Amîtsoq gneiss and Ameralik dykes and were thus emplaced at an early 
stage in the development of the area. Some ultramafic bodies show apparent transitions from talc and anthophylite centred bodies into carbonate-rich units.

The majority of better preserved sediments are chemical precipitates (ironstones, impure recrystallised cherts, carbonates) and volcanogenic clastic rocks. Magnesium-rich layers are common and include a $\mathrm{Mg}$ analogue of quartz-banded ironstone in which the place of magnetite is taken by anthophyllite interbanded with quartz or magnetite and quartz. Pelites are generally dark and iron-rich and contain garnet and staurolite. Large tourmaline crystals have been reported from several localities and smaller crystals are common in thin sections suggesting the pelites are boron-rich.

The depositional environment of the Isua succession is not known. There is no evidence for deposition on a continental margin nor is there clear evidence about the depth of water under which the sediments were deposited, although there is some evidence for sedimentary reworking of the sediments in shallow water conditions. There is a constant association between clastic sediments and chemical sediments on a scale of 1 to $2 \mathrm{~m}$ up to $100 \mathrm{~m}$. There is considerable evidence that the present composition of many of the layers has been altered radically by leaching, possibly by circulating water in a volcanic environment.

(6) The state of preservation and metamorphic assemblages within the post-3600 m.y., pre-2800 m.y. Ameralik dykes change markedly in different parts of the Isua area depending largely on the local effects of post-dyke deformation and the competency contrast between dykes and host rocks. Within the core of Amitsoq gneisses partially surrounded by the Isua supracrustal belt (see fig. 6, Bridgwater et al., 1976) the dykes preserve their primary intrusion forms and locally their primary mineralogy. Detailed observations from two localities showed that at least 2 of the rectilinear N-S dykes are younger than podded E-W dykes. Within the supracrustal belt many of the Ameralik dykes are highly deformed and are commonly rotated parallel to the structures in the supracrustals. In calcareous horizons they are frequently boudined. They develop a strong linear fabric and amphibolite facies mineralogy. One to two metre wide isoclinally folded dykes have been noted on both shores of the lake Imarssuaq and close to the main iron-ore occurrence at the margin of the inland ice. Thicker dykes from the same general localities are unfolded although they may develop a shear fabric. In the southern and western parts of the area the dykes are mainly in amphibolite facies. Near the iron-ore body the dykes are in greenschist facies. Chemical analyses of dykes from this area show that they contain up to 10 per cent $\mathrm{H}_{2} \mathrm{O}$.

The variable state of preservation of the Ameralik dykes in the Isua area has lead to difficulty in their identification. Particular care is necessary when selecting basic material for geochemical studies of the Isua supracrustals to be certain that the most homogeneous units collected are not Ameralik dykes.

\section{Recommendations}

In the Godthåbsfjord area the group would like to see detailed geochemical and isotopic studies carried out on suites of gneiss from well exposed outcrops in which chronological relationships between different phases of injection are clear. In the Isua area we feel that considerable more field work is necessary before proper geochemical studies can be carried out. We recommend that structural mapping be undertaken by a field geologist experienced in identifying rock units which have been through extreme shear deformation. We further 
suggest that this work should be carried out in collaboration with a sedimentologist experienced in volcanoclastic rocks.

\section{References}

References prior to 1976 are given in Escher, A. \& Watt, W. S. (edit.) 1976: Geology of Greenland. Copenhagen: Geol. Surv. Greenland.

Allaart, J. H. 1976: The pre-3760 m.y. old supracrustal rocks of the Isua area, central West Greenland, and the associated occurrence of Quartz-banded ironstone. In B. F. Windley, The Early History of the Earth, 177-189. London: Wiley.

Baadsgaard, H. 1976: Further U-Pb dates on zircons from the early Precambrian rocks of the Godthaabsfjord area, West Greenland. Earth Planet. Sci. Let. 33, 261-267.

Baadsgaard, H., Collerson, K. D. \& Bridgwater, D. in press: The Archaean gneiss complex of northern Labrador: preliminary U-Th-Pb geochronology. Can. J. Earth Sci.

Bridgwater, D. \& Collerson, K. D. 1977: On the origin of early Archaean gneisses: a reply. Contr. Miner. Petrol. 62, 179-191.

Collerson, K. D. \& Bridgwater, D. 1979: Metamorphic development of early Archean tonalitic and trondhjemitic gneisses: Saglek area. Labrador. In Barker, F. Trondhjemites, dacites and related rocks. Elsevier.

McGregor, V. R. \& Mason, B. 1977: Petrogenesis and geochemistry of metabasaltic and sedimentary enclaves in the Amîtsoq gneisses, West Greenland. Amer. Miner. 62, 887-904.

Moorbath, S., O'Nions, R. K. \& Pankhurst, R. J. 1975: The evolution of Early Precambrian crustal rocks at Isua, West Greenland - geochemical and isotopic evidence. Earth Planet. Sci. Let. 27, 229-239.

Moorbath, S. \& Pankhurst, R. J. 1976: Further rubidium-strontium age and isotope evidence for the nature of the late Archaean plutonic event in West Greenland. Nature, Lond. 262, 124-126.

Wells, P. R. A. 1976: Late Archaean metamorphism in the Buksefjord region, Southwest Greenland. Contr. Miner. Petrol. 56, 229-242.

H.B.,

Department of Geology, University of Alberta,

Edmonton 7,

Alberta TG6 2E1,

Canada.

I.E.,

Precambrian Subdivision, Geological Survey of Canada, 601 Booth Street, Ottawa KIA 0E8, Canada.

W.G.,

Geologisk Museum,

Sarsgatan 1,

Oslo 5 ,

Norway

V.R.M.,

Atangmik,

3912 Sukkertoppen,

Greenland.
K.D.C.,

Research School of Earth Sciences, Australian National University, Canberra, Australia,

(on leave from Memorial University, Newfoundland).

B.E.G., Department of Geology, University of Western Ontario, London Ontario N6A 5B7,

Canada.

G.H.,

Department of Earth and Space Sciences, State University of New York, Stony Brook, New York 11794, U.S.A.

S.M. \& P.T., Department of Geology and Mineralogy, Oxford University, Parks Road, Oxford $O X 13 P R$,

U.K.

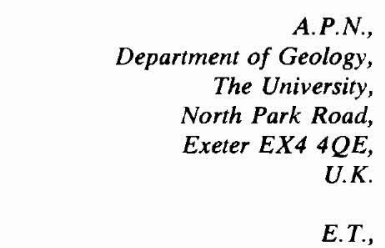

Norges Geologiske Undersøkelse, Leiv Eirikssonsvei 39, 7001 Trondheim, Norway. J.W., Department of Geology, Imperial College, London S.W. 7 , U.K. 